\title{
The life cycle of Stephos longipes - an example for cryopelagic coupling in the Weddell Sea (Antarctica)
}

\author{
F. Kurbjeweit ${ }^{1}$, R. Gradinger ${ }^{2}$, J. Weissenberger ${ }^{1}$ \\ ${ }^{1}$ Alfred-Wegener-Institut für Polar- und Meeresforschung, Columbusstr., D-27568 Bremerhaven, Germany \\ ${ }^{2}$ Institut für Polarökologie, Universität Kiel, Wischhofstr. 14, Geb. 12, D-24148 Kiel, Germany
}

\begin{abstract}
Distribution, abundance and age composition of the calanoid copepod Stephos longipes (Giesbrecht) were studied in the southeastern Weddell Sea in January-February 1991. Samples were taken in the water column with a multiple closing net in 5 depth strata down to $1000 \mathrm{~m}$. Concurrent samples were taken from drifting ice floes and from a $1 \mathrm{~m}$ deep layer underneath the pack ice (under ice water layer: UIWL) using a specially designed pump. S. longipes was the predominant calanoid copepod at most stations throughout the continental shelf area within the upper $50 \mathrm{~m}$ of the water column. Generally, abundances inside the pack ice floes exceeded those in the UIWL by 1 to 3 orders and the water column below by 3 to 5 orders of magnitude respectively. The mean population stage was lowest inside the ice floes followed by the UIWL and the water column. Also, nauplii and young copepodite stages (CI and $\mathrm{CII}$ ) often outnumbered all other metazoan groups within and beneath the ice. Highest densities of S. longipes $\left(>90000 \mathrm{~m}^{-3}\right.$ ) were observed in ice floes and UIWL samples where platelet ice was particularly frequent, probably as a result of the extreme stickiness of $S$. longipes eggs and their attachment to floating ice crystals. Fecal pellets of S. longipes, collected in the UIWL, were in most cases filled with sea ice algae. Our results indicate that the life cycle of $S$. longipes is closely associated with the sea ice, especially platelet ice layers, where a high algal standing crop can sustain a sufficiently high secondary production in an otherwise food limited habitat. Thus, $S$. longipes uses a completely different strategy than large calanoid copepods in the Antarctic which do not inhabit sea ice at any given time during their life cycle.
\end{abstract}

\section{INTRODUCTION}

The sea ice cover plays an important role in structuring marine habitats of polar oceans (see Eicken 1992). It reduces the available light intensity and, thus, the productivity of the pelagic communities, but it also serves as a habitat containing a typical flora and fauna. These ice and sub-ice communities numerically consist mainly of bacteria, algae, fungi, and protozoans (e.g. Horner 1985, Garrison \& Buck 1991). The few investigations focusing on the possible role of metazoans in the ice community were nearly entirely done at Arctic coastal sites

Carey (1985) summarized the knowledge about the Arctic ice-associated fauna, where gammarid amphipods dominate the sympagic communities. Lønne \& Gulliksen (1991) described the habitat selection and behavior of 3 dominant amphipod species. Gradinger et al. (1991) demonstrated that the Arctic in-ice fauna is dominated by ciliates and acoel turbellarians, while crustaceans were of minor importance. Runge et al. (1991) recently summarized the multidisciplinary investigations on coupling processes between ice algae and metazoan zooplankton in the southeastern Hudson Bay. Here, calanoid copepods like Calanus glacialis and Pseudocalanus minutus graze on ice algae during the night time, when they actively migrate from deeper water layers to the interface between ice and water.

Andriashev (1968) developed a concept highlighting the significance of the sea ice biota for the Antarctic biosphere, where the biomass of the ice algae is comparable to the standing stock of phytoplankton blooms in some productive seas of the northern hemisphere. 
He suggested that this standing crop supplies 2 major groups of animals, those that live at least temporarily inside the ice floes (in-ice fauna) or those that never directly enter the ice floes, but are to some degree trophically dependant on the ice community (sub-ice fauna). The in-ice fauna consists of amphipods (RakusaSuszczewski 1972, Richardson \& Whitaker 1979, Hopkins \& Torres 1988), copepods (Tanimura et al. 1984, Hopkins \& Torres 1988, Waghorn \& Knox 1988, Dahms et al. 1990), foraminifera (Lipps \& Krebs 1974, Dieckmann et al. 1991), polychaetes (Andriashev 1968) and fingerlings of Pagothenia (=Trematomus) borchgrevinki (Andriashev 1968). The sub-ice fauna consists mainly of euphausiids like Euphausia crystallorophias (Andriashev 1968, Bradford 1978), Euphausia superba (Marr 1962, Marschall 1988), adult cryopelagic fish such as Pagothenia borchgrevinki (Bradford 1978, Hoshiai \& Tanimura 1981) and Dissostichus mawsoni (Andriashev 1968) and presumably the calanoid copepod Calanus propinquus, that seems to live beneath the sea ice during winter (Nöthig et al. 1991).

In the present study, we examined the distribution and abundance of the ice, sub-ice (under ice water layer, UIWL) and water column fauna with special reference to the calanoid copepod Stephos longipes and its age composition. In all 3 habitats we observed $S$. longipes as a predominant component of the species assemblages. As a result of the abundance data and age composition analysis of $S$. longipes we established a conceptual model of its life cycle in comparison to other Antarctic copepods.

\section{METHODS}

In January-February 1991 plankton samples were taken from RV 'Polarstern' in the southeastern Weddell Sea, Antarctica, by means of a vertically towed multiple opening and closing net $(100 \mu \mathrm{m}$, $0.25 \mathrm{~m}^{2}$; Weikert \& John 1981) in 5 depth strata down to $1000 \mathrm{~m}$ chosen according to water column stratification. The volume of water filtered was calculated using a flow meter (Hydrobios, Kiel, Germany). On 3 permanent drift stations (Stns 126 to 128) and on 1 transect from close to the shelf ice to the deep ocean (Fig. 1) samples were concurrently obtained from the sea ice and an approximately $1 \mathrm{~m}$ deep layer underneath the sea ice (UIWL). Ice cores were taken with a modified 3" CRREL ice auger and cut into 1 to $10 \mathrm{~cm}$ long sections for the determination of the

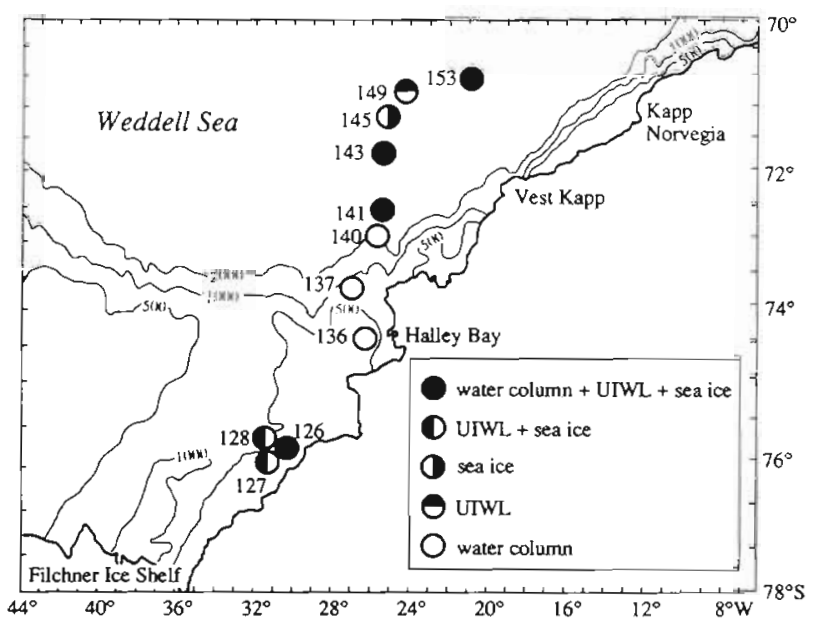

Fig. 1. Station map of the Weddell Sea with depth $(\mathrm{m})$ and shelf ice (thick line) contours. Symbols indicate kind of sample taken on each station. UIWL: under ice water layer

vertical distribution of sea ice organisms (for details of ice sample treatment see Gradinger et al. 1991).

The submersible under-ice pump included a collector-tube ( $4 \mathrm{~cm}$ diameter, $190 \mathrm{~cm}$ length) equipped with a $20 \mathrm{~mm}$ gauze at the opening to prevent damage to the collected organisms by larger pieces of ice. The lower end of the tube was fixed in a rectangular position to the under-ice surface covering a sampling area of about $2.2 \mathrm{~m}^{2}$. Organisms were collected on a $60 \mu \mathrm{m}$ gauze within a $40 \mathrm{l}$ plastic container directly on the ice floe. Pumping rates were determined at the beginning and at the end of the pumping time (approximately $24 \mathrm{l} \mathrm{min}^{-1}$ ). Pumping times ranged from 30 to $120 \mathrm{~min}$.

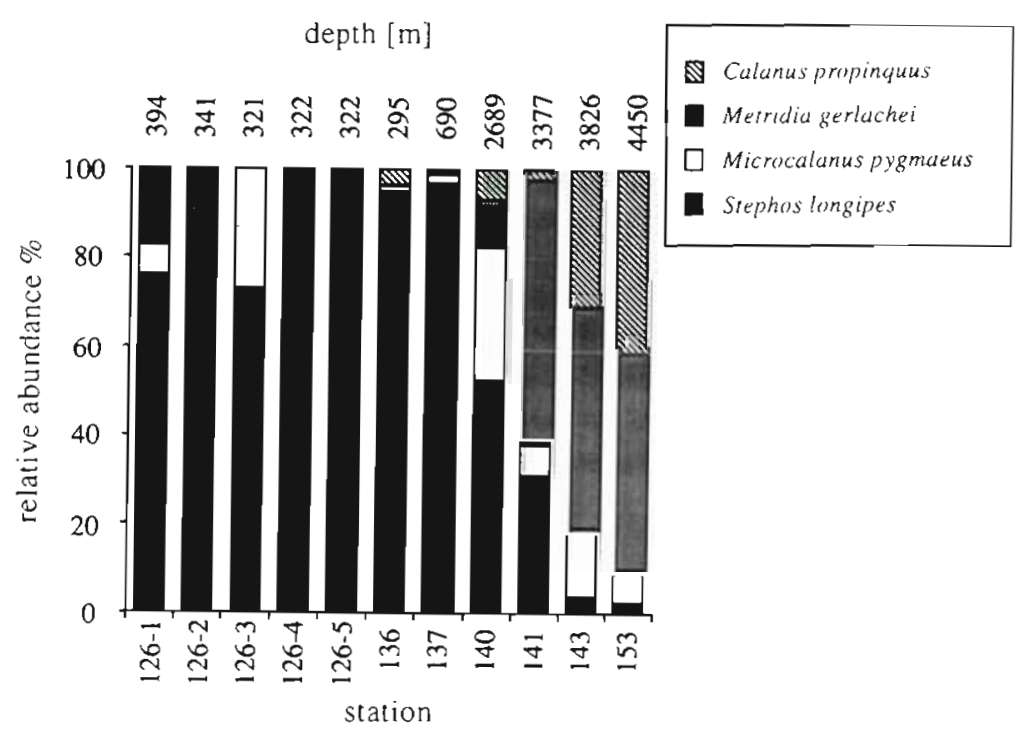

Fig. 2. Relative abundances of Stephos longipes, Calanus propinquus, Metridia gerlachei and Microcalanus pygmaeus within the upper $50 \mathrm{~m}$ of the water column, and depth at each station 
During the drift stations, the submersible pump as well as ice cores were taken from different locations to study spatial heterogeneity in both habitats. A detailed summary of all station positions and procedures is given by Bathmann et al. (1992).

Samples were preserved in borax buffered formalin ( $4 \%$ final concentration). Depending on the abundance of organisms, the whole sample or at least 30 specimens per stage and species were enumerated under a dissecting microscope.

Mean population stage for Stephos longipes was calculated using the abundance data according to Huntley \& Escritor (1991)

$$
[\mathrm{S}]=\left(\mathrm{N}_{\mathrm{Cl}}+2 \mathrm{~N}_{\mathrm{CII}}+\ldots .+6 \mathrm{~N}_{\mathrm{CVl})} / \sum \mathrm{N}\right.
$$

where $N_{C I}, N_{C I l}, \ldots N_{C V I}=$ number of specimens of copepodite stages CI, CII, ... CVI, and $\sum \mathrm{N}=$ the sum of all individuals.

For the determination of possible food sources of Stephos longipes fecal pellets from the pump samples were examined in detail using light microscopy.

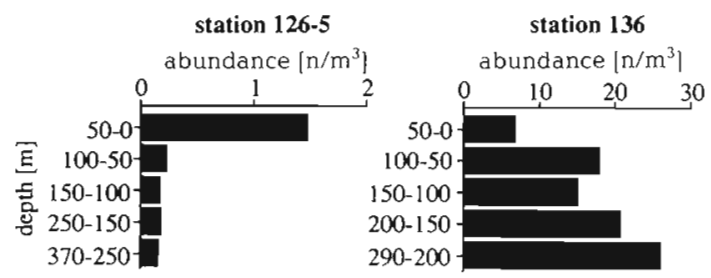

Fig. 3. Stephos longipes. Vertical distribution and abundance in the water column at Stns $126-5 \& 136$. Note different scales

\section{RESULTS}

Stephos longipes constituted 2 to $100 \%$ of the total abundance of calanoid copepods in the investigation area in the upper $50 \mathrm{~m}$ of the water column (Fig. 2). It was the dominant species at most stations in the continental shelf area. At stations with increasing water depth the calanoid copepods Calanus propinquus, Microcalanus pygmaeus and Metridia gerlachei dominated in the surface layer. The vertical distribution pattern of $S$. longipes within the water column was characterized by a large decrease from the upper layers to greater water depth (e.g. Stn 126-5, Fig. 3). S. longipes showed an inverse distribution pattern with highest abundances in the deepest water layer just above the sea floor only at Stn 136 (Fig. 3).

The abundance of Stephos longipes at drift Stn 126 was $<2$ ind. $\mathrm{m}^{-3}$ over the entire water column, and thus, 1 order of magnitude less than at the other shelf Stns 136 \& 137 further north (Fig. 4). Along the transect (Stns 136 to 153) the abundance decreased with distance from the shelf ice and increasing water depth, respectively. High abundances of $S$. longipes were observed inside the pack ice floes and in the under ice water layer (UIWL) on most stations (Fig. 4). Generally, abundance of copepodite stages inside the ice floes exceeded those in the UIWL by 1 to 3 orders of magnitude and those in the water column by 3 to 5 orders of magnitude. The abundance of nauplii could only be determined within the sea ice and in the UIWL due to their small size and the different sampling equipments
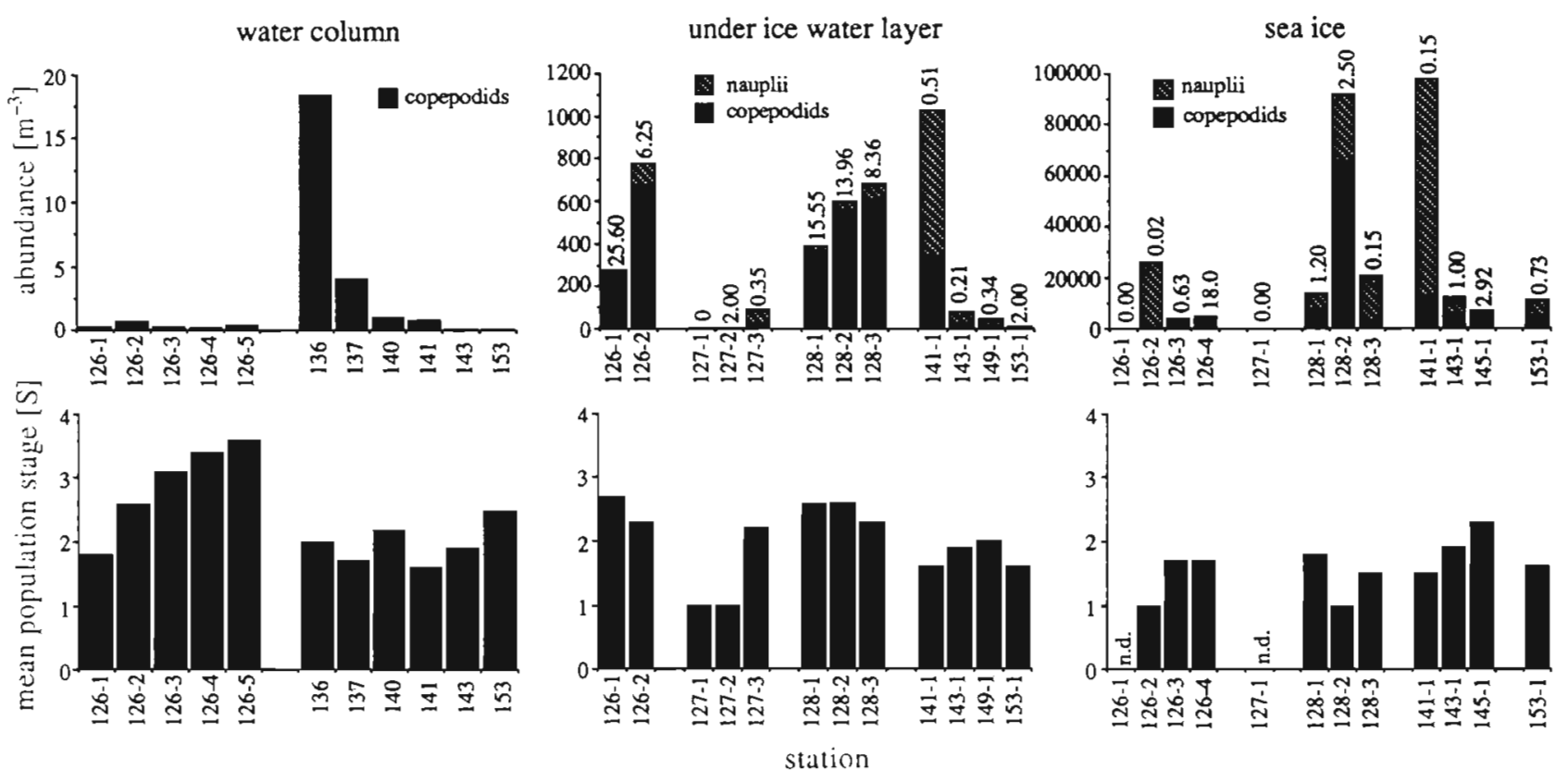

Fig. 4. Stephos longipes. Average abundance and mean population stage $|S|$ in the water column, in the under ice water layer and inside the ice floes. Note different scales for abundance data. n.d.: not determined, because no copepodite stages were present. Ratios of abundance of copepodite stages vs nauplii given as numbers above bars 


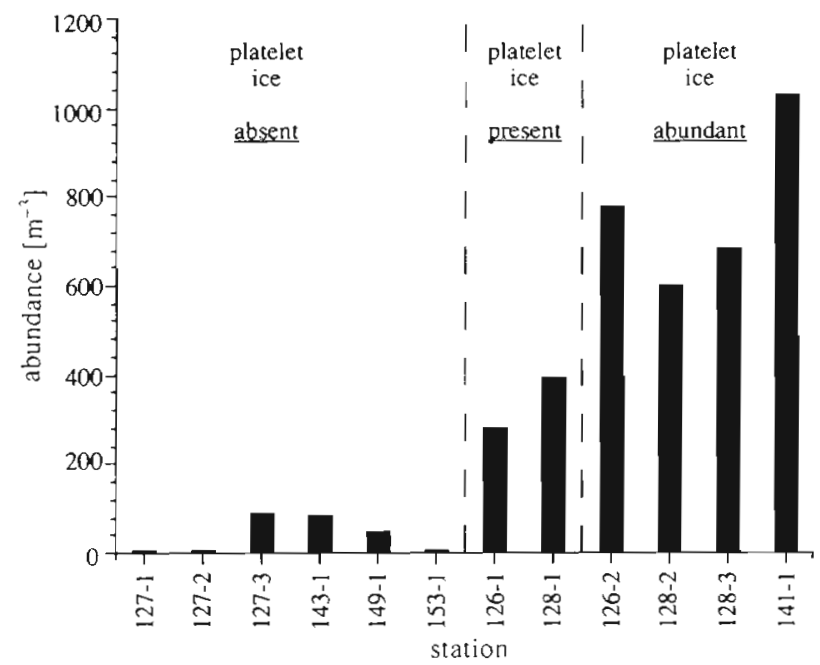

Fig. 5. Abundance of Stephos longipes in the UIWL in relation to the relative abundance of platelet ice

used. Inside the ice floes and in the UIWL they in almost all cases outnumbered the copepodite stages especially at the oceanic stations (Stns 141 to 153, Fig. 4)
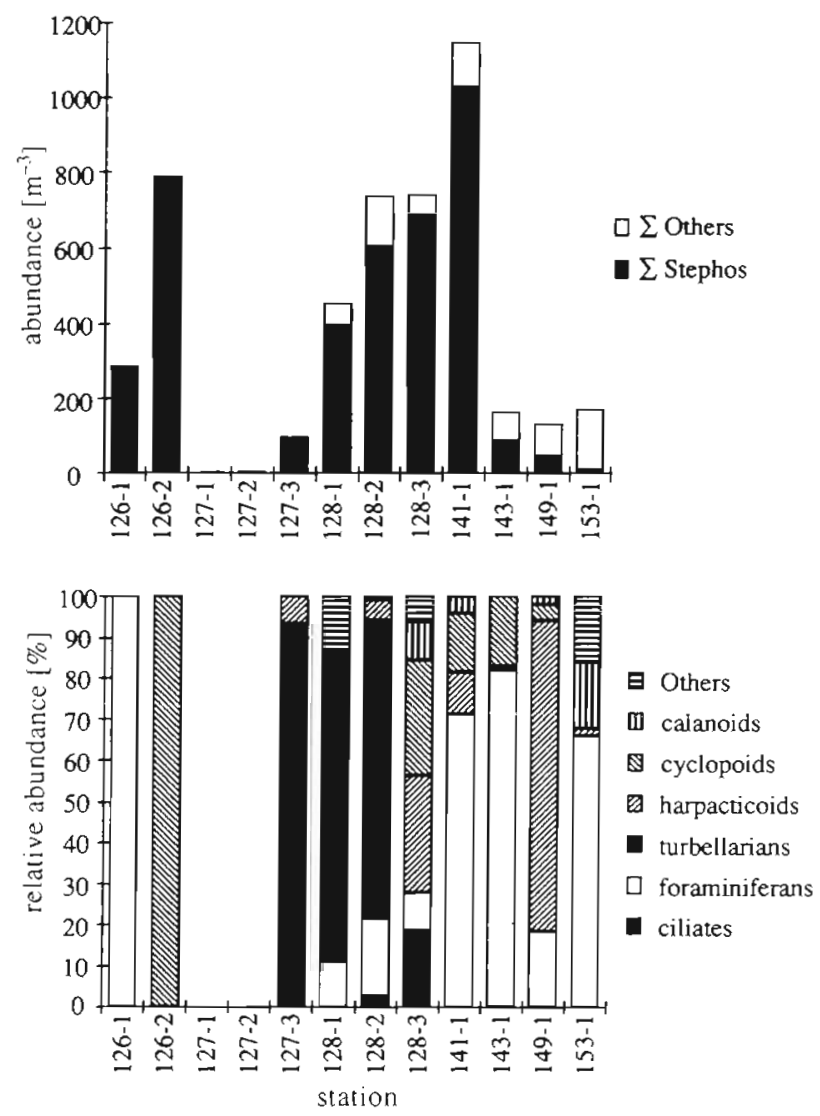

Fig. 6. Abundance of Stephos longipes and other groups of organisms and relative abundance of the other groups of organism without $S$. longipes in the UIWL
The mean population stage calculated for copepodite stages of Stephos longipes differed among the 3 habitats. The mean population stage inside ice floes ([S] $=1.5 \pm 0.4)$ was significantly $(p=0.01$, $t$-test) lower than in the UIWL $([S]=2.0 \pm 0.6)$ and in the water column ( $[S]=2.4 \pm 0.7$ ) (Fig. 4). The average copepodid nauplii ratio within the pack ice floes was significantly $(p=0.005)$ lower than in the UIWL.

In the UIWL the abundance of Stephos Iongipes was apparently related to the occurrence of platelet ice (Fig. 5) and this species outnumbered other metazoan groups and sometimes even larger protozoans (Fig. 6). While $S$. longipes was by far the predominant species beneath the sea ice at all shelf stations, its importance decreased with distance to the shelf ice edge and increasing water depth (Fig, 6). The composition of the fauna other than $S$. longipes was heterogenous and showed no relation to the sampling sites. Protozoans like ciliates and heterotrophic flagellates were probably underestimated due to cell damage or their small size. The foraminiferan Neogloboquadrina pachyderma dominated the fauna at Stns 141, 143 \& 153 and was the second most abundant group beside
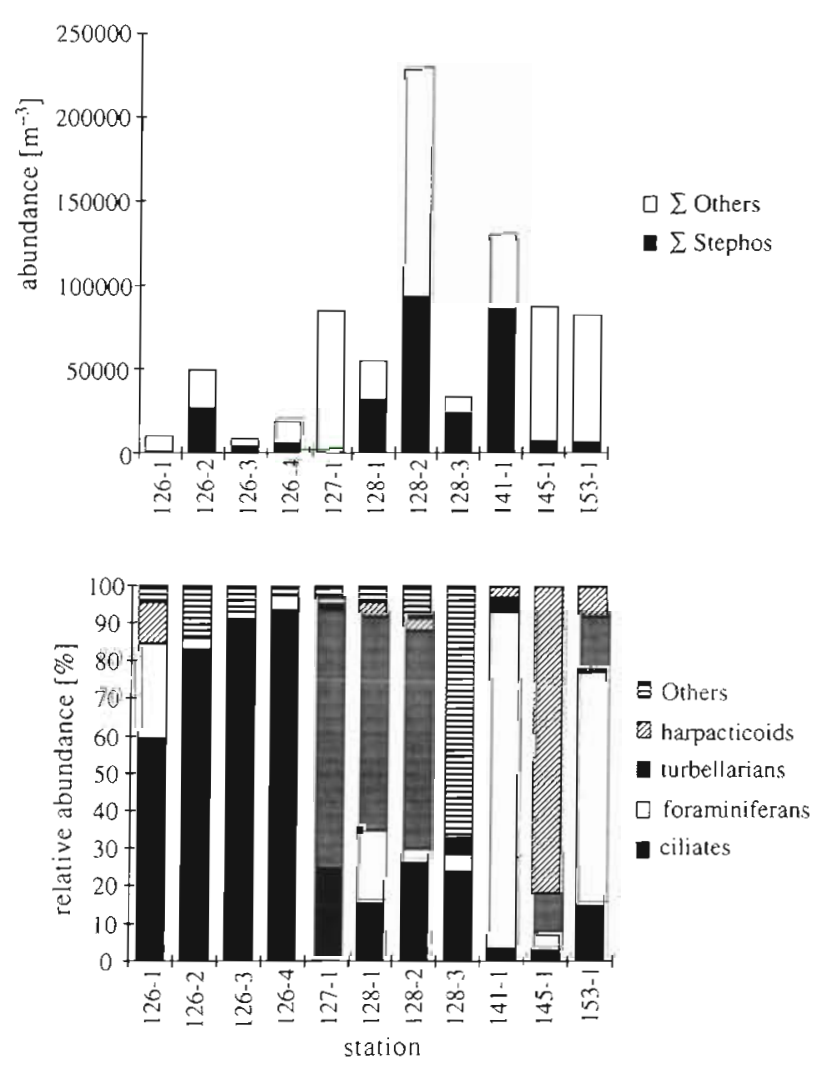

Fig. 7. Abundance of Stephos longipes and other groups of organisms and relative abundance of the other groups of organism without $S$. longipes inside ice floes 
S. longipes in about thirty percent of all sub-ice samples. Studies by Berger (1971) and Brummer et al. (1986) demonstrated that over $80 \%$ of a natural population of planktonic foraminifera are smaller than $100 \mu \mathrm{m}$. Although we used a $60 \mu \mathrm{m}$ gauze for the concentration of the UIWL fauna a significant part of the foraminiferan population might have been lost during this process. In 3 samples, turbellarians were common and in 2 they were the second most abundant group after $S$. longipes. Other copepods were almost negligible in abundance except cyclopoids of the genera Oithona and Oncaea and a harpacticoid, belonging to the genus Drescheriella.

Inside the ice floes Stephos longipes was one of the most important species and dominated in about $45 \%$ of all samples (Fig. 7), but, in contrast to the sub-ice samples, there was no clear distribution pattern obvious for $S$. longipes within the sea ice. Only a slight correlation between the abundances inside the ice floes and in the UIWL $\left(r^{2}=0.667, n=9\right)$ was found. The composition of the remaining fauna beside $S$. longipes showed that ciliates as well as foraminifera, acoel turbellarians and harpacticoids were the most important organism groups in the sea ice. Besides S. longipes no

\section{ice core 127-1}
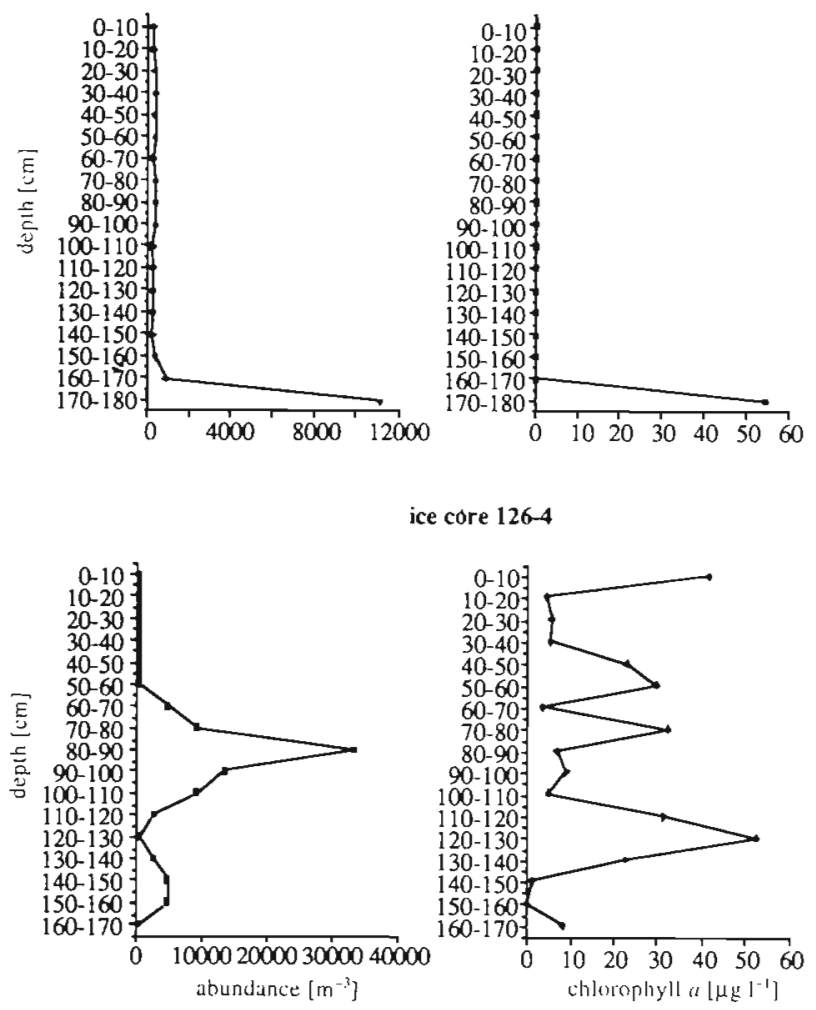

Fig. 8. Distribution patterns of Stephos longipes and chlorophyll a within sea ice cores $127-1$ and $126-4$ cyclopoid or calanoid copepod species was found inside the pack ice floes (Fig. 7).

No clear correlation was found between the vertical distribution of Stephos longipes and chlorophyll a inside the ice floes. In about $50 \%$ of all ice cores highest chlorophyll a concentrations were found in the lowermost centimeters of the ice floes, where $S$. longipes was also most abundant (Fig. 8). Other ice core samples showed strong vertical variations of both chlorophyll $a$ and abundance of S. longipes (Fig. 8). In all ice cores the phytoplankton stock mainly consisted of typical ice algae like Nitzschia cylindrus, $N$. curta and other pennate diatoms. Fecal pellets of $S$. longipes, collected from the UIWL samples, contained only frustules of pennate diatoms like Nitzschia spp.

\section{DISCUSSION}

Our results show that the life cycle of the calanoid copepod Stephos longipes includes stages inhabiting the 2 habitats, water column and sea ice. The overall abundance of $S$. longipes increased from the water column to the sea ice. The mean population stage [S] for copepodite stages decreased from the water column to the sea ice, and its nauplii were only abundant beneath and especially inside the ice floes. Thus, $S$. longipes seems to adopt a similar strategy to Paralabidocera antarctica in the Indian sector of the Antarctic (Fukuchi \& Tanimura 1981, Tanimura et al. 1984, 1986, Hoshiai \& Tanimura 1986), in McMurdo Sound in the Pacific sector (Foster 1987) and in meromictic lakes (Bayly 1978, Bayly \& Burton 1987) or as P. grandispinosa at White Island in McMurdo Sound (Waghorn \& Knox 1988).

The first hint for a close relationship of Stephos longipes with sea ice was given by Schnack-Schiel (1987). In late winter/early spring she collected large numbers of late developmental stages in the UIWL using a NIPR-I net (Fukuchi et al. 1979), while it was found in the upper $100 \mathrm{~m}$ of the water column in comparatively low numbers. In contrast, during JanuaryFebruary S. longipes was more abundant in the upper $100 \mathrm{~m}$ of the water column than in the sea ice. Schnack-Schiel suggested that $S$. longipes lives and reproduces in the layer directly below the ice in late winter/early spring. After the onset of large scale melting the population is released into the water column. For the western part of the Weddell Sea, Hopkins \& Torres (1988) mentioned S. longipes as the most common metazoan species in sea ice samples collected during March over deep water (depth $>2000 \mathrm{~m}$ ) close to the ice edge. This is in good agreement with results of Schnack-Schiel (unpubl.), who found S. longipes also to be abundant within the sea ice on oceanic 
stations in the western Weddell Sea in SeptemberOctober and with our results for Stn 141. In contrast, the abundance of $S$. longipes in the water column decreased drastically with distance from the shelf ice in the Weddell Sea (this study) and the Lazarev Sea (Kurbjeweit unpubl.). Therefore, the appearance of S. longipes in offshore areas is probably due to advection of sea ice from the shelf towards the centre of the Weddell Gyre. Our results show the significance of $S$. longipes as part of the sea ice and sub-ice community in the shelf areas.

The chlorophyll a concentrations within and beneath the sea ice are several orders of magnitude higher than in the underlying water column (Fig. 9). Our observations on the contents of fecal pellets demonstrated that Stephos longipes is mainly feeding on ice algae as Hoshiai et al. (1987) demonstrated for Paralabidocera antarctica. Reproduction experiments with $S$. longipes showed significantly higher egg production rates with ice algae as food than with planktonic diatoms (Kurbjeweit unpubl.). Therefore, food limitation for this species, as well as for other organism groups inhabiting the sea ice or the UIWL, seems unlikely, because, even during winter, high ice algal standing stocks have been observed in contrast to low phytoplankton stocks in the water column (Hoshiai 1977. 1981, Fukuchi et al. 1985, Spindler et al. 1990, Nöthig et al. 1991). Especially in the bottom centimeters of the pack ice floes and in the platelet ice layer (Fig. 9), conditions seem to be favourable for organisms as small as $S$. longipes or $P$. antarctica. Inside the ice brine channels of the ice floes and the platelet ice layer nauplii hatch in environments giving both enough food (Nöthig et al. 1991, Smetacek et al. 1992) and perfect protection from predation by krill (Schnack-Schiel 1987), fish (Hoshiai \& Tanimura 1981, Hubold \& Ekau 1990) and carnivorous zooplankton like ctenophores and amphipods (Hamner et al. 1989). Thus, the sea ice habitats serve as a 'nursery' for the larval copepods. Conclusively, $S$. longipes belongs to the group of the in-ice fauna, which lives at least temporarily in the lower part of the ice (Andriashev 1968). It was also found in intermediate layers of the sea ice, depending on the size of brine channels and pockets, whose structure have been described in detail by Weissenberger et al. (1992). The salinity of the brine is a function of the sea ice temperature and can exceed values of $120 \%$. Thus, nauplii and early copepodite stages of $S$. longipes must be able to regulate their body fluids over a wide salinity range as do other osmoconformers such as certain harpacticoids (Dahms et al. 1990).

At this stage only a preliminary picture of the life cycle of Stephos longipes can be drawn (see Fig. 9). Adult females and males occur in a 1:1 ratio from midNovember until mid-December just beneath the sea

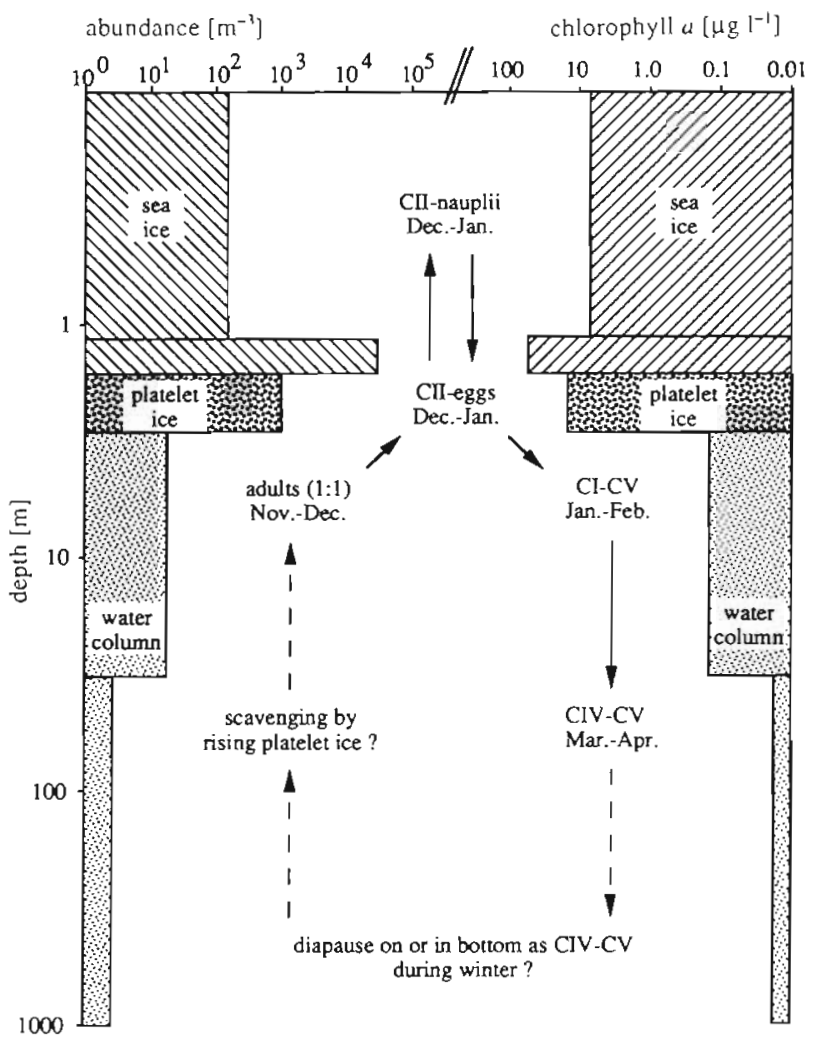

Fig. 9. Schematic representation of the abundance of different developmental stages of Stephos longipes and phytoplankton standing stock within and below the sea ice, and in the upper $1000 \mathrm{~m}$ of the water column

ice for mating on the western and eastern shelf of the Weddell Sea (Kurbjeweit unpubl.). These copepods either actively migrate to the surface or may be passively carried to the surface by dislodged anchor ice from the bottom (Dayton et al. 1969) or platelet ice formed in the water column (Dieckmann et al. 1986). Since the eggs of $S$. longipes are extremely sticky compared to those of other calanoid copepods, and females need direct contact with a substrate for egg-laying (Kurbjeweit unpubl.), they may attach their eggs directly to ice crystals or ice platelets. The harvesting of particles (sediment particles, algae, foraminifera) by drifting ice crystals, which results in a transport to the sea surface, has been demonstrated by several investigators le.g. Ackley 1982, Reimnitz et al. 1990, Dieckmann et al. 1991). These observations may result from surface stickiness of particles which was shown for sea ice algae by Riebesell et al. (1991). At the end of December or beginning of January, young copepodite stages leave the brine channels inside the ice floes to feed in the UIWL and in the upper water column developing to CIV and CV by the end of March (Kurbjeweit unpubl.). These stages presumably migrate to greater 
depths where they overwinter on or even within the bottom sediments with similar behavior to other species of the genus in tropical or boreal areas (McWilliam et al. 1981, Thain et al. 1981, Ohtsuka \& Hiromi 1987. Jacoby \& Greenberg unpubl.). This hypothesis is partly confirmed by Schnack-Schiel (unpubl.) who found copepodite stages CIV and CV dominating in deeper water layers and above the bottom in the eastern Weddell Sea in mid April. During this time of the year $S$. longipes was almost absent from the sea ice and the UIWL and constituted a major fraction of the sea ice community only on 1 station where platelet ice occurred. It is not yet known if CIV and CV copepodite stages feed during the winter and where they mature to adults. Due to the fact that the different developmental stages inhabit different levels within and beneath the ice and in the water column, intraspecific competition is minimal for this species and adults and juveniles may feed on different resources.

Thus, Stephos longipes is able to sustain a sufficiently high secondary production within and just beneath the sea ice where high algal biomass is found compared to an otherwise food limited habitat (Fig. 9). Consequently, $S$. longipes might play an important role as a grazer on ice algae and perhaps protozoans during spring and early summer within the sea ice, while its young copepodite stages may be prey for krill, fish fry and other carnivorous zooplankton later in the year in the water column. Its life cycle is therefore at least partially comparable with that of Paralabidocera antarctica, whose life cycle is completed within the sea ice (Hoshiai et al. unpubl.). However, it differs considerably from life histories of large copepods such as Calanoides acutus, which overwinters as CIV and CV in deeper water layers below $500 \mathrm{~m}$ (Voronina 1966 , 1972, 1978, Marin 1988a, b, Schnack-Schiel et al. 1991) or Calanus propinquus, which seems to feed in the water column beneath the sea ice as CIII during winter (Nöthig et al. 1991). Whether S. Iongipes actively carries out ontogenetic migrations and how it differs from ecologically similar species as Paralabidocera spp. must be examined in more detail.

Acknowledgements. We are indebted to the captain and the crew of RV 'Polarstern' for their frequent assistance. We thank Richard Steinmetz and Kerstin Beyer for their support of our study. We are grateful to Dr Sigrid Schiel, Dr Michael Spindler and 3 unknown referees for helpful comments on the manuscript. This is AWI contribution Nr. 582.

\section{LITERATURE CITED}

Ackley, S. F. (1982). Ice scavenging and nucleation: two mechanisms for incorporation of algae into newly formed sea ice. EOS 63: 54
Andriashev, A. P. (1968). The problem of life community associated with Antarctic fast ice. In: Currie, R. I. (ed.) Symp. Antarctic oceanography. Scott Polar Res. Inst., Cambridge, p. $147-155$

Bathmann, U., Schulz-Baldes, M., Fahrbach, E., Smetacek, V., Hubberten, H.-W. (1992). The expeditions ANTARKTIS IX/1-4 of the research vessel 'Polarstern' in 1990/91. Ber. Polar forsch. 100: 1-403

Bayly, I. A. E. (1978). The occurrence of Paralabidocera antarctica (I. C. Thompson) (Copepoda: Calanoida: Acartiidae) in an Antarctic saline lake. Aust. J. mar. Freshwat. Res. 29: 817-824

Bayly, I. A. E., Burton, H. R. (1987). Vertical distribution of Paralabidocera antarctica (Copepoda: Calanoida) in Ace Lake, Antarctica, in summer. Aust. J. mar. Freshwat. Res. 38: $537-543$

Berger, W. H. (1971). Sedimentation of planktonic foraminifers. Mar. Geol. 11: 325-358

Bradford, J. M. (1978). Sea ice organisms and their importance to the Antarctic ecosystem. N.Z. Antarctic Rec. 1: $43-50$

Brummer, G. J. A., Hemleben, C., Spindler, M. (1986). Planktonic foraminiferal ontogeny: new perspectives for micropaleontology. Nature 319: 50-52

Carey, A. G. (1985). Marine ice fauna, Arctic. In: Horner, R. A. (ed.) Sea ice biota. CRC Press, Boca Raton, p. 173-203

Dahms, H.-U., Bergmans, M., Schminke, H. K. (1990). Distribution and adaptations of sea ice inhabiting Harpacticoida (Crustacea, Copepoda) of the Weddell Sea (Antarctica). P.S.Z.N. I: Mar. Ecol. 11: 207-236

Dayton, P. K., Robilliard, G. A., Devries, A. L. (1969). Anchor ice formation in McMurdo Sound, Antarctica, and its biological effects. Science 163: 273-274

Dieckmann, G., Rohardt, G., Helmer, H., Kipfstuhl, J. (1986) The occurrence of ice platelets at 250 meters depth near the Filchner Ice Shelf and its significance for sea ice biology. Deep Sea Res. 33: 141-148

Dieckmann, G. S., Spindler, M., Lange, M. A., Ackley, S. F. Eicken, H. (1991). Antarctic sea ice: a habitat for the foraminifera Neogloboquadrina pachyderma. J. foraml. Res. 21: 182-189

Eicken, H. (1992). The role of sea ice in structuring the Antarctic ecosystems. Polar Biol. 12: 3-13

Foster, B. A. (1987). Composition and abundance of zooplankton under the spring sea-ice of McMurdo Sound, Antarctica. Polar Biol. 8: 41-48

Fukuchi, M., Tanimura, A. (1981). A preliminary note on the occurrence of copepods under sea ice near Syowa Station, Antarctica. Mem. natn. Inst. polar Res., Tokyo (Spec. Issue) $34: 37-43$

Fukuchi, M., Tanimura, A., Hoshiai, T. (1979). 'NIPR-I': a new plankton sampler under sea ice. Bull. Plankton Soc. Japan 26: $104-109$

Fukuchi, M., Tanimura, A., Ohtsuka, H. (1985). Zooplankton community conditions under sea ice near Syowa Station, Antarctica. Bull mar. Sci. 37: 518-528

Garrison, D. L., Buck, K. R. (1991). Surface-layer sea ice assemblages in Antarctic pack ice during the austral spring: environmental conditions, primary production and community structure. Mar. Ecol. Prog. Ser. 75: 161-172

Gradinger, R., Spindler, M., Henschel, D. (1991). Development of Arctic sea-ice organisms under graded snow cover. Polar Res. 10: 295-307

Hamner, W. M., Hamner, P. P., Obst, B. S., Carleton, J. H (1989). Field observations on the ontogeny of schooling Euphausia superba furciliae and its relationsship to ice in Antarctic waters. Limnol. Oceanogr. 23: 451-456 
Hopkins, T L., Torres, J. J (1988). The zooplankton community in the vicinity of the ice edge, Western Weddell Sea, March 1986. Polar Biol. 9: 79-87

Horner, R. A. (1985). Sea ice biota. CRC Press, Boca Raton

Hoshiai, T. (1977). Seasonal changes of ice communities in sea ice near Syowa Station, Antarctica. In: Dunbar, M. J. (ed ) Polar oceans: Proc. Polar Ocean Conf., Montreal May 1974. Calgary Arct. Inst. North Am., Calgary, p. $463-503$

Hoshiai, T. (1981). Proliferation of ice algae in the Syowa Station area, Antarctica. Mem natn. Inst. polar Res. Tokyo (Spec. Issue) 34:1-12

Hoshiai, T., Tanimura, A. (1981). Copepods in the stomach of a nototheniid fish. Trematomus borchgrevinki fry at Syowa Station, Antarctica. Mem. natn. Inst. polar Res. Tokyo (Spec. Issue) 34: 44-48

Hoshiai, T., Tanimura, A. (1986). Sea ice meiofauna at Syowa Station, Antarctica. Mem. natn. Inst. polar Res., Tokyo (Spec. Issue) 44: 118-124

Hoshiai, T., Tanimura, A., Watanabe, K. (1987). Ice algae as food of an Antarctic ice associated copepod, Paralabidocera antarctica (I.C. Thompson). Proc. NIPR Symp. Polar Biol. 1: 105-111

Hubold, G., Ekau, W. (1990). Feeding patterns of post-larval and juvenile Notothenioids in the Southern Weddell Sea (Antarctica). Polar Biol. 10: 255-260

Huntley, M., Escritor, F. (1991). Dynamics of Calanoides acutus (Copepoda: Calanoida) in Antarctic coastal waters. Deep Sea Res. 38: 1145-1167

Lipps, J. H., Krebs, W. N. (1974). Planktonic foraminifera associated with Antarctjc sea ice. J. foraml. Res. 4: 80-85

Lonne, O. J., Gulliksen, B. (1991). On the distribution of sympagic macro-fauna in the seasonally ice covered Barents Sea. Polar Biol. 11: 457-469

Marin, V. (1988a). Independent life cycles: an alternative to the asynchronism hypothesis for Antarctic calanoid $\mathrm{CO}$ pepods. Hydrobiologia 167/168: 161-167

Marin, V (1988b). Qualitative models of the life cycles of Calanoides acutus, Calanus propinquus, and Rhincalanus gigas. Polar Biol. 8: 439-446

Marr, J. W. S. (1962). The natural history and geography of the Antarctic krill (Euphausia superba Dana). 'Discovery' Rep. 32: $33-464$

Marschall, H.-P. (1988). The overwintering strategy of Antarctic krill under the pack-ice of the Weddell Sea. Polar Biol. 9: 129-135

McWilliam, P. S., Sale, P. F., Anderson, D. I (1981). Seasonal changes in resident zooplankton sampled by emergence traps in One Tree Lagoon, Great Barrier Reef. J. exp. mar. Biol. Ecol. 52: 185-203

Nöthig, E. M., Bathmann, U., Jennings, J, Fahrbach, E., Gradinger, R., Gordon, L., Makarov, R. (1991). Regional relationships between biological and hydrographical properties in the Weddell Gyre in late austral winter 1989. J. mar. Chem. 35: 325-336

Ohtsuka, S., Hiromi, J (1987). Calanoid copepods collected from the near-bottom in Tanabe Bay on the Pacific coast of the middle Honshu, Japan. 3. Stephidae. Publ. Seto mar. biol. Lab. 32: 219-232

Rakusa-Suszczewski, S. (1972). The biology of Paramaera walkeri Stebbing (Amphipoda) and the Antarctic sub-fast ice community. Polskie Arch. Hydrobiol. 19: 11-36

Reimnitz, E., Kempema, E. W., Weber, W. S., Clayton, J R.,
Payne, J. R. (1990). Suspended matter scavenging by rising frazil ice. In: Ackley, S. F., Weeks, S. F. (eds.) Sea ice properties and processes. Proc. W. F. Weeks Sea Ice Symp., Cold Regions Research and Engineering Laboratory, CRREL Monogr. 90-1, Hanover, NH, p. 97-100

Richardson, M. C., Whitaker, T M. (1979). An Antarctic fast-ice food chain: observations on the interaction of the amphipod Pontogeneia antarctica Chevreux with iceassociated microalgae. Br. Antarct. Surv. Bull. 47: 107-115

Riebesell, U., Schloss, I., Smetacek, V. (1991). Aggregation of algae released from melting sea ice: implications for seeding and sedimentation. Polar Biol. 11: 239-248

Runge, J. A., Therriault, J. C., Legendre, L., Demers, S. (1991). Coupling between ice microalgal productivity and the pelagic, metazoan food web in southeastern Hudson Bay: a synthesis of results. Polar Res. 10: 325-338

Schnack-Schiel, S. (1987). The winter-expedition of RV 'Polarstern' to the Antarctic (ANT V/1-3). Ber. Polarforsch. 39: $1-159$

Schnack-Schiel, S. B., Hagen, W., Mizdalski, E. (1991). Seasonal comparison of Calanoides acutus and Calanus propinquus (Copepoda: Calanoida) in the southeastern Weddell Sea Antarctica. Mar. Ecol. Prog. Ser. 70: 17-27

Smetacek, V., Scharek, R., Gordon, L. I., Eicken, H., Fahrbach, E., Rohardt, G., Moore, S. (1992). Early spring phytoplankton blooms in ice platelet layers of the southern Weddell Sea, Antarctica. Deep Sea Res. 39: 153-168

Spindler, M., Dieckmann, G. S., Lange, M. A. (1990). Seasonal and geographic variations in sea ice community structure of the Weddell Sea, Antarctica. In: Kerry, K. R., Hempel, G. (eds.) Antarctic ecosystems, ecological change and conservation. Springer, Berlin, p. 129-135

Tanimura, A., Fukuchi, M., Hoshiai, T (1986). Seasonal change in the abundance of zooplankton and species composition of copepods in the ice-covered sea near Syowa Station, Antarctica. Mem. natn. Inst. polar Res., Tokyo (Spec. Issue) 40: 212-220

Tanimura, A., Fukuchi, M., Ohtsuka, H. (1984). Occurrence and age composition of Paralabidocera antarctica (Calanoida, copepoda) under the fast ice near Syowa Station, Antarctica. Mem. natn. Inst. polar Res., Tokyo (Spec. Issue) 32: 81-86

Thain, V. M., Jones, J., Kitching, J. A. (1981). Distribution of zooplankton in relation to the thermocline and oxycline in Lough Ine, County Cork. Ir. Nat. J. 20: 292-295

Voronina, N. M. (1966). The zooplankton of the Southern Ocean: Some study results. Oceanology 6: 557-563

Voronina, N. M. (1972). The spatial structure of interzonal copepod populations in the Southern Ocean. Mar. Biol. 15: $336-343$

Voronina, N. M. (1978). Seasonal variation in the age composition and vertical distribution of common zooplankton species in the Southern Ocean. Oceanology 18: 335-339

Waghorn, E. J., Knox, G. A. (1988). Summer tide-crack zooplankton at White Island, McMurdo Sound, Antarctica. N.Z. J. mar. Freshwat. Res. 22: 577-582

Weickert. H., John, H. Chr. (1981). Experiences with a modified Be multiple opening-closing plankton net. J. Plankton Res. 3: $167-177$

Weissenberger, J., Dieckmann, G., Gradinger, R., Spindler, M. (1992). Sea ice: A cast technique to examine and analyze brine pockets and channel structure. Limnol Oceanogr. 37: 179-183

Manuscript first received: September 21, 1992

Revised version accepted: April 22, 1993 